\title{
Comprehensive assessment of association between TLR4 gene polymorphisms and cancer risk: a systematic meta-analysis
}

\author{
Lu Ding ${ }^{1}$, Qifeng Jiang ${ }^{1}$, Guang Li ${ }^{1}$, Jia Shen ${ }^{1}$, Jiayin Du ${ }^{1}$, Xiaochen Lu ${ }^{1}$ and Xingliang \\ Xiong ${ }^{1}$ \\ ${ }^{1}$ Department of Medical Informatics, Chongqing Medical University, Chongqing, 400016, China
}

Correspondence to: Xingliang Xiong, email: xlxiong@cqmu.edu.cn

Keywords: cancer risk, toll-like receptor, TLR4, SNP, meta-analysis

Received: July 18, 2017 Accepted: September 25, 2017 Published: October 06, 2017

Copyright: Ding et al. This is an open-access article distributed under the terms of the Creative Commons Attribution License 3.0 (CC BY 3.0), which permits unrestricted use, distribution, and reproduction in any medium, provided the original author and source are credited.

\section{ABSTRACT}

Previous studies have explored the association between toll-like receptor 4 (TLR4) polymorphisms and risk of various cancers, but the results remained controversial. To obtain an assessment of the effect of TLR4 polymorphisms (rs4986790, rs4986791 and rs11536889) on cancer risk, fifty-five articles (containing 20107 cases and 28244 controls) were recruited for meta-analysis. Our result indicated that two Single Nucleotide Polymorphisms (SNP) in TLR4 were associated with decreased cancer risk for rs4986791: $O R=0.764,95 \% C I: 0.652-0.894, P=0.001$ in allele model; OR $=0.769,95 \% C I: 0.650-0.909, P=0.002$ in recessive model; $O R=0.505,95 \%$ CI: $0.352-0.726, P=0.000$ in dominant model; for 11536889: $O R=0.927,95 \%$ CI: $0.872-0.984, P=0.013$ in allele model; $O R=0.926,95 \% \mathrm{CI}: 0.862-0.944, P=$ 0.034 in recessive model. In terms of subgroup analyses sorted by ethnicity, only polymorphism of rs4986791 had a significant influence on decrease of cancer risk among both Caucasian and Asian populations. The findings suggested that TLR4 polymorphisms may serve as a genetic risk factor for cancers.

\section{INTRODUCTION}

Toll-like receptors (TLRs) were important innate immune molecules which were used for specific recognition to adjust the adaptive immune response by identifying the pathogen-associated molecular patterns (PAMPs). In addition, TLRs stimulated the immune system and promoted the development of cancer due to its potential chronic inflammation [1-3]. In recent years, many research findings revealed the functions and molecular mechanisms of TLRs in cancers $[4,5]$, which indicated that TLRs may play a role in the cancer occurrence and development. There were 13 kinds of TLRs found in the mammal body, among them, only TLR2 and TLR4 can bond with glycosyl ligand and their intracellular adapters were mainly consist of Toll/IL-1 homologous receptor(TIR), myeloid differentiation factor 88 (My88), TIR domain containing adapter-inducing interferon- $\beta$ (TRIF), TRIF-related adaptor molecule (TRAM) and MyD88 adaptor-like (MAL).
Recent studies indicated that TLR4 expressed on many cells as the bridge between the natural immunity and acquired immunity was able to produce proinflammatory factors and chemotactic factors after combining with ligands such as lipopolysaccharide(LPS) and teichoic acid [6]. Moreover, TLR4 signals were transmitted through MyD88-dependency and MyD88-independency. After combining with ligands, TLR4 transmitted the stimulation signals into cell nucleus which was activated by a series of protein cascade reactions [7]. Such behavior led to the activation of important immune gene transcription factors such as NF- $\mathrm{KB}$, activator protein- 1 and interferon regulatory factor (IRF) that induced the synthesis and release of relevant cell factors like IL-1, IL-2,TNF- $\alpha$ and IFN and enabled the acquired immune action by promoting the maturity of dendritic cells (DC), thus, stimulating a series of immune reactions with different pathogenic microorganism in the end [8]. The MyD88 dependent way mainly mediated the combination of interleukin-1 receptor-associated kinase-1 (IRAK-1), IRAK4 and TLR4, and dissociated 
IRAK-1 from receptor complex after its phosphorylation activating necrosis tumor factor-associated factor 6(TRAF-6) through binding with it. TRAF-6 then stimulated the inhibitor of nuclear factor kappa-B kinase (IKK) complex by exciting transforming growth factor- $\beta$-activating kinase 1 (TAK1), induced I $\kappa \mathrm{B}$ phosphorylation to release and transmit NF- $\kappa \mathrm{B}$ into cell nucleus enabling the relevant genetic transcription $[9,10]$. The MyD88 independent way was mainly related to LPS-induced interferon induced protein-10 (IP-10), IFN-regulate gene 1 (IRG-1) and glucocorticoid attenuated responsegene-16 (GARG16) expressions and the DC maturity.

Numerous publications demonstrated that the existence of single nucleotide polymorphism (SNPs) made it possible for affecting TLR4 signaling, which was responsible for hyporesponsiveness and infection of fungus, virus and bacteria and the expression of TLR4 had a close association with the development of breast cancer [11-14], lung cancer [15], prostate cancer [16-21], colorectal cancer [22-26] and liver cancer [25, 27-29]. Due to the inconsistence of these findings, arising probably from inadequacy of sample size, we made a comprehensive study to better understand the association between TLR4 gene and cancer risk. There were 20107 cases and 28244 controls totally in the research and for rs2986790 and rs2986791, the amount of cases and controls were 9105 and 11338, 4416 and 7379, respectively. There were 6586 cases and 9527 controls to evaluate the association between rs11536889 polymorphism and the risk of cancer.

\section{RESULTS}

\section{Studies included in the meta-analysis}

In the beginning, there were 166 relevant articles searched mainly from PubMed, of which 26 duplicates were excluded. And 43 articles were eliminated because of their irrelevance with cancer. After getting rid of studies focusing on other gene instead of TLR4, meta-analysis, studies lacking comparison between case and control and studies having few valuable data, 55 publications were eventually included. As elaborated in Figure 1, the flow chart of selecting, 29, 30, 15 articles were suitable for investigating the relation between rs2986790, rs2986791 and rs11536889 polymorphisms and cancer risk, respectively. In addition, detail information on included articles were shown in Supplementary Table 1, while studies disagreeing with HWE containing seven for rs4986790, three for rs4986791 and one for rs11536889 were shown in bold.

\section{Meta-analysis results}

TLR4 rs4986790 polymorphism and cancer risk. Before the analysis, we tested the sensitivity of this SNP and found an article affecting the sensitivity greatly through leaveone-out method. Therefore, this article written by Hold GL1 [30] about gastric cancer was excluded in our study. We then evaluated the association between rs4986790 polymorphism and the risk of cancer through analyzing data gained from 20 articles, containing 9105 cases and 11338 controls. However, few connection between rs4986790 polymorphism and risk of cancer was found under three genetic models shown in Table 1 and Supplementary Figure 1.

TLR4 rs4986791 polymorphism and cancer risk. To investigate the relation between the polymorphism and cancer risk, we searched 27 studies for useful data and 4416 cases and 7379 controls were analyzed. Table 2 and Supplementary Figure 2 demonstrated rs4986791 polymorphism always had a association with decrease of cancer risk among overall population(allele model: $\mathrm{OR}=$ 0.764, 95\% CI: 0.652-0.894, $P=0.001$; recessive model: $\mathrm{OR}=0.769,95 \% \mathrm{CI}: 0.650-0.909, P=0.002$; dominant model: $\mathrm{OR}=0.505,95 \% \mathrm{CI}: 0.352-0.726, P=0.000)$, Caucasian population (allele model: $\mathrm{OR}=0.790,95 \% \mathrm{CI}$ : 0.646-0.966, $P=0.022$; recessive model: $\mathrm{OR}=0.798$, 95\% CI: 0.649-0.982, $P=0.033$; dominant model: OR $=0.430,95 \%$ CI: 0.205-0.904, $P=0.026)$ and Asian population (allele model: $\mathrm{OR}=0.633,95 \% \mathrm{CI}$ : $0.555-$ $0.793, \mathrm{P}=.000$; recessive model: $\mathrm{OR}=0.656,95 \% \mathrm{CI}$ : $0.548-0.786, P=0.000$; dominant model: $\mathrm{OR}=0.532$, 95\% CI: $0.351-0.806, P=0.003)$ in three genetic models.

TLR4 rs11536889 polymorphism and cancer risk. Taking 14 articles, containing 6586 cases and 9527 controls, into consideration, we noticed a connection between rs11536889 polymorphism and decreased risk of cancer in overall population under two genetic models (allele model: $\mathrm{OR}=0.927,95 \% \mathrm{CI}: 0.872-0.984$, $P=0.013$; recessive model: $\mathrm{OR}=0.926,95 \% \mathrm{CI}: 0.862-$ $0.944, P=0.034)$. The similar association was also found for rs11536889 in Asian population under allele model $(\mathrm{OR}=0.916,95 \% \mathrm{CI}=0.845-0.992, P=0.031)$ and dominant model $(\mathrm{OR}=0.777,95 \% \mathrm{CI}=0.640-0.943, P=$ 0.011 ) illustrated in Table 3 and Supplementary Figure 3.

\section{Evaluation of heterogeneity}

As shown in Tables 1-3 and Supplementary Table 2, slight heterogeneities existed in overall comparisons $\left(\mathrm{P}_{\mathrm{h}}=\right.$ $0.126, I^{2}=27.3 \%$ for $\mathrm{rs} 4986790 ; \mathrm{P}_{\mathrm{h}}=0.031, I^{2}=36.6 \%$ for rs4986791; $\mathrm{P}_{\mathrm{h}}=0.400, I^{2}=4.7 \%$ for $\left.\mathrm{rs} 11536889\right)$. We performed logistical meta-regression to evaluate the source of heterogeneity among all studies and found that ethnicity had a significant influence on heterogeneity, while cancer type, number of alleles, sample size and genotyping methods could not greatly influence the initial heterogeneity. According to Cochrane handbook [31], however, the heterogeneity whose value of $P$ is lower than $50 \%$ is acceptable confirming the credibility of our study.

\section{Publication bias and sensitivity analysis}

The publication bias of included literatures was evaluated through the Begg's test under allele model. As displayed in Figure 2, there was no evident publication 
Table 1: Meta-analysis of the association between rs4986790 polymorphism and cancer risk

\begin{tabular}{|c|c|c|c|c|c|c|c|c|c|c|}
\hline \multirow[t]{2}{*}{ Population } & \multirow[t]{2}{*}{$N$} & \multicolumn{3}{|c|}{ A vs. G(Allele model) } & \multicolumn{3}{|c|}{$\begin{array}{c}\text { AA vs. AG + GG } \\
\text { (Recessive model) }\end{array}$} & \multicolumn{3}{|c|}{$\begin{array}{c}\text { AA }+ \text { AG vs. GG } \\
\text { (Dominant model) }\end{array}$} \\
\hline & & OR(95\%CI) & POR & $\mathbf{P h}$ & OR $(95 \% \mathrm{CI})$ & POR & $\mathbf{P h}$ & OR $(95 \% C I)$ & POR & $\mathbf{P h}$ \\
\hline Overall & 21 & $\begin{array}{c}0.871 \\
(0.763-0.995)\end{array}$ & 0.289 & 0.126 & $\begin{array}{c}0.919 \\
(0.839-1.005)\end{array}$ & 0.065 & 0.212 & $\begin{array}{c}1.320 \\
(0.855-2.039)\end{array}$ & 0.293 & 0.804 \\
\hline Caucasian & 14 & $\begin{array}{c}0.946 \\
(0.854-1.048)\end{array}$ & 0.289 & 0.048 & $\begin{array}{c}0.925 \\
(0.831-1.030)\end{array}$ & 0.155 & 0.087 & $\begin{array}{c}1.497 \\
(0.853-2.626)\end{array}$ & 0.254 & 0.584 \\
\hline Asian & 3 & $\begin{array}{c}0.771 \\
(0.571-1.042)\end{array}$ & 0.091 & 0.886 & $\begin{array}{c}0.780 \\
(0.526-2.363)\end{array}$ & 0.134 & 0.785 & $\begin{array}{c}0.469 \\
(0.134-1.642)\end{array}$ & 0.236 & 0.835 \\
\hline African & 1 & $\begin{array}{c}1.227 \\
(0.602-2.497)\end{array}$ & 0.573 & - & $\begin{array}{c}1.115 \\
(0.526-2.363)\end{array}$ & 0.776 & - & $\begin{array}{c}3.628 \\
(0.172-76.396)\end{array}$ & 0.407 & - \\
\hline Mixed & 3 & $\begin{array}{c}0.965 \\
(0.795-1.170)\end{array}$ & 0.716 & 0.282 & $\begin{array}{c}0.941 \\
(0.768-1.152)\end{array}$ & 0.551 & 0.246 & $\begin{array}{c}1.499 \\
(0.593-3.789)\end{array}$ & 0.392 & 0.966 \\
\hline
\end{tabular}

The results were in bold if the $\mathrm{P}_{\mathrm{OR}}<0.05$. Odd ratio (OR), 95\% confidence interval (95\% CI) and $\mathrm{P}_{\mathrm{OR}}$ were tested to evaluate the association, while $\mathrm{P}_{\mathrm{h}}$ was examined for heterogeneity

bias in these studies $(P=0.496$ for rs4986790, after the article of Hold GL was excluded from this study; $P=0.297$ for $\mathrm{rs} 4986791 ; P=0.827$ for $\mathrm{rs} 11536889$, respectively). The leave-one-out sensitivity analysis was also performed to examine the effects of individual article on the pooled ORs. The result, illustrated in Figure 3, indicated that the pooled OR had no evident change after removing any studies.

\section{DISCUSSION}

In this study, we conducted a meta-analysis of 55 independent articles concerning the association between
TLR4 polymorphisms and cancer risk. As a result, rs4986791 polymorphism had a significant association with decreased cancer risk under 3 genetic model. And similar association was also found between rs11536889 and risk of cancer in overall and Asian populations.

TLR4 gene, located in chromosome 9q32-q33, was an important receptor of lipopolysaccharide and played a key role in immune responses thorough activation of nuclear factor kappa-light-chain-enhancer [32, 33]. It, thus, became a focus on infection and immunity in current studies. Polymorphisms of rs4986790 and rs4986791 in exon 3, leading respectively to the substitution of Asp299Gly and Thr399Ile amino acid and downregulating the expression of several genes in the

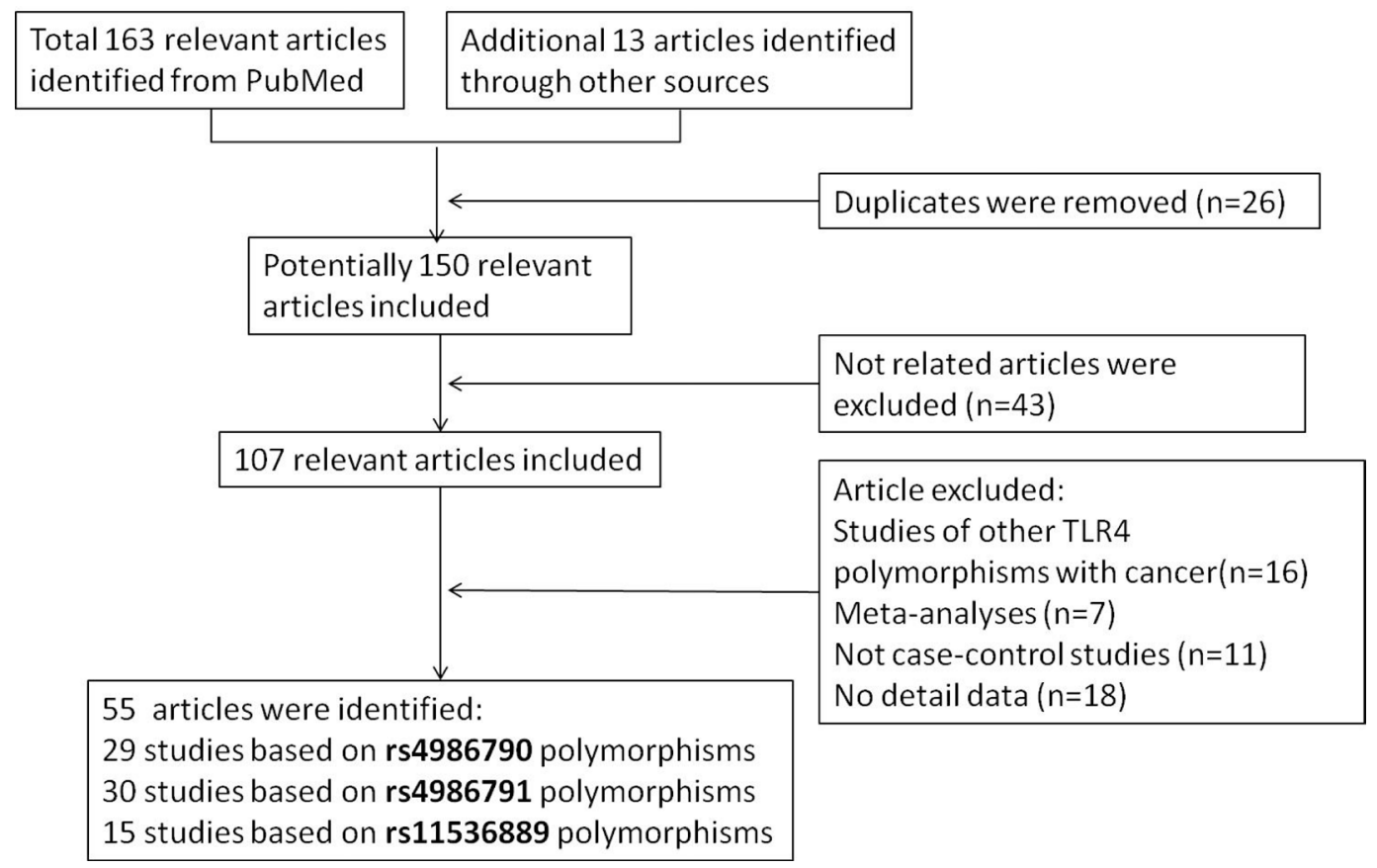

Figure 1: Flow diagram of included and excluded publications. 
Table 2: Meta-analysis of the association between rs4986791 polymorphism and cancer risk

\begin{tabular}{|c|c|c|c|c|c|c|c|c|c|c|}
\hline \multirow[t]{2}{*}{ Population } & \multirow[t]{2}{*}{$N$} & \multicolumn{3}{|c|}{ C vs. T(Allele model) } & \multicolumn{3}{|c|}{$\begin{array}{c}\text { CC vs. CT + TT } \\
\text { (Recessive model) }\end{array}$} & \multicolumn{3}{|c|}{ CC + CT vs. TT (Dominant model) } \\
\hline & & OR(95\%CI) & $\mathbf{P}_{\mathrm{OR}}$ & $\mathbf{P}_{\mathrm{h}}$ & OR (95\% CI) & $\mathbf{P}_{\mathrm{OR}}$ & $\mathbf{P}_{\mathrm{h}}$ & OR(95\%CI) & $\mathbf{P}_{\mathrm{OR}}$ & $\mathbf{P h}$ \\
\hline Overall & 27 & $\begin{array}{c}0.764 \\
(0.652-0.894)\end{array}$ & 0.001 & 0.031 & $\begin{array}{c}0.769 \\
(0.650-0.909)\end{array}$ & 0.002 & 0.035 & $\begin{array}{c}0.505 \\
(0.352-0.726)\end{array}$ & 0.000 & 0.777 \\
\hline Caucasian & 19 & $\begin{array}{c}0.790 \\
(0.646-0.966)\end{array}$ & 0.022 & 0.082 & $\begin{array}{c}0.798 \\
(0.649-0.982)\end{array}$ & 0.033 & 0.095 & $\begin{array}{c}0.430 \\
(0.205-0.904)\end{array}$ & 0.026 & 0.635 \\
\hline Asian & 5 & $\begin{array}{c}0.633 \\
(0.555-0.793)\end{array}$ & 0.000 & 0.336 & $\begin{array}{c}0.656 \\
(0.548-0.786)\end{array}$ & 0.000 & 0.397 & $\begin{array}{c}0.532 \\
(0.351-0.806)\end{array}$ & 0.003 & 0.663 \\
\hline African & 1 & $\begin{array}{c}2.090 \\
(0.809-5.399)\end{array}$ & 0.128 & - & $\begin{array}{c}2.165 \\
(0.822-5.704)\end{array}$ & 0.118 & - & - & - & - \\
\hline Mixed & 2 & $\begin{array}{c}1.397 \\
(0.224-8.700)\end{array}$ & 0.720 & 0.117 & $\begin{array}{c}1.408 \\
(0.219-9.065)\end{array}$ & 0.719 & 0.114 & - & - & - \\
\hline
\end{tabular}

The results were in bold if the $\mathrm{P}_{\mathrm{OR}}<0.05$ Odd ratio (OR), 95\% confidence interval (95\% CI) and $\mathrm{P}_{\mathrm{OR}}$ were tested to evaluate the association, while $\mathrm{P}_{\mathrm{h}}$ was examined for heterogeneity.

TLR4 TRAM/TRIF signaling pathway [34], was associated with endotoxin hyporesponsiveness [35], gram-negative septic shock [36] and atherogenesis [37]. However, analyses focusing on them did not reach a consensus on cancer risk and some proved they had a nonnegligible impact on breast cancer [11, $13]$ and digestive cancer $[23,26]$, while the others believed that

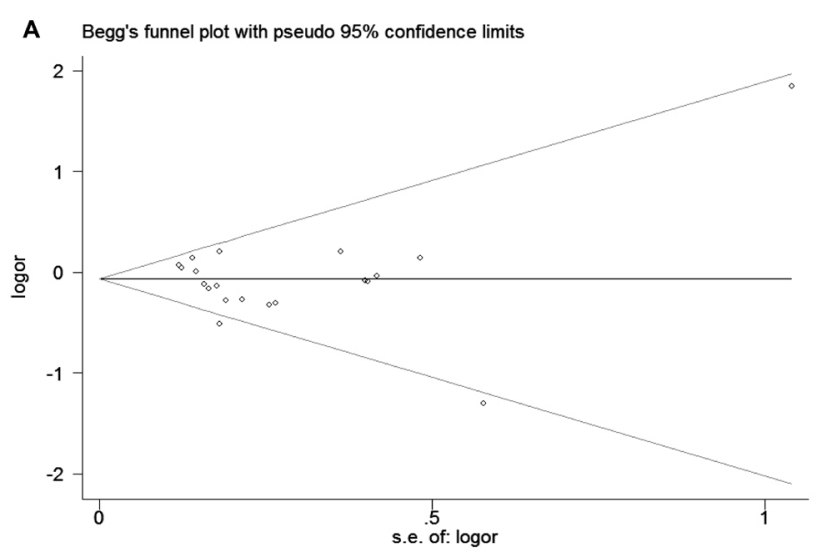

no evident could support significant association with gastric cancer [38, 39], bladder cancer [40], prostate cancer [20], leukemia [41]. To minimized the effects of sample size, a large amount of publications on variant cancers were collected in this study and the consequence reflected there was a significant association between rs4986791 polymorphism and the decrease

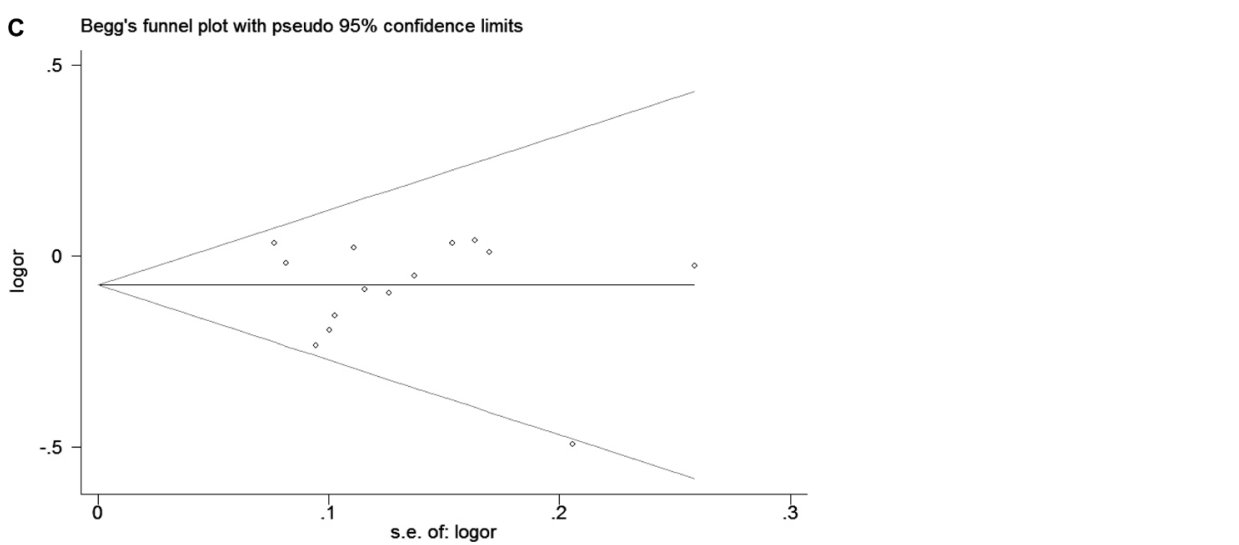

Figure 2: Begg's funnel plot for publication bias test of (A) rs4986790, (B) rs4986791 and (C) rs11536889 polymorphisms. Each point stand for an individual article in overall population under allele model. s.e., standardized effect. 
Table 3: Meta-analysis of the association between rs11536889 polymorphism and cancer risk

\begin{tabular}{lcccccccccc}
\hline \multirow{2}{*}{ Population } & & \multicolumn{3}{c}{ G vs. C(Allele model) } & \multicolumn{3}{c}{$\begin{array}{c}\text { GG vs. GC+CC } \\
\text { (Recessive model) }\end{array}$} & \multicolumn{2}{c}{ GG+GC vs. CC(Dominant model) } \\
\cline { 2 - 10 } & & OR(95\%CI) & POR & Ph & OR(95\%CI) & POR & Ph & OR(95\%CI) & POR & Ph \\
\hline \multirow{2}{*}{ Overall } & 14 & 0.927 & 0.013 & 0.400 & 0.926 & 0.034 & 0.446 & 0.853 & 0.060 & 0.508 \\
& & $(0.872-0.984)$ & & & $(0.862-0.944)$ & & & $(0.723-1.007)$ & & \\
Caucasian & 6 & 0.941 & 0.193 & 0.722 & 0.919 & 0.106 & 0.529 & 1.082 & 0.623 & 0.824 \\
& & $(0.858-1.031)$ & & & $(0.829-1.018)$ & & & $(0.790-1.483)$ & & \\
Asian & 8 & 0.916 & 0.031 & 0.159 & 0.932 & 0.164 & 0.264 & 0.777 & 0.011 & 0.438 \\
& & $(0.845-0.992)$ & & & $(0.844-1.029)$ & & & $(0.640-0.943)$ & & \\
\hline
\end{tabular}

The results were in bold if the $P_{\mathrm{OR}}<0.05$. Odd ratio (OR), 95\% confidence interval $(95 \% \mathrm{CI})$ and $\mathrm{P}_{\mathrm{OR}}$ were tested to evaluate the association, while $\mathrm{P}_{\mathrm{h}}$ was examined for heterogeneity.

of cancer risk while polymorphism of rs4986790 was found irrelevant to cancer risk. The influence of rs11536889, whose genetic variation contributed to translational regulation of TLR4, possibly by binding to microRNAs [42], on decrease of cancer risk was also prominent which was consistent with results of previous articles $[43,44]$.

As for stratified analyses by ethnicity, polymorphism of rs4986791 had a prominent effect on decreased cancer risk of Caucasian and Asian. Also, decreased cancer risk among Asian population was associated with rs 11536889 polymorphism.

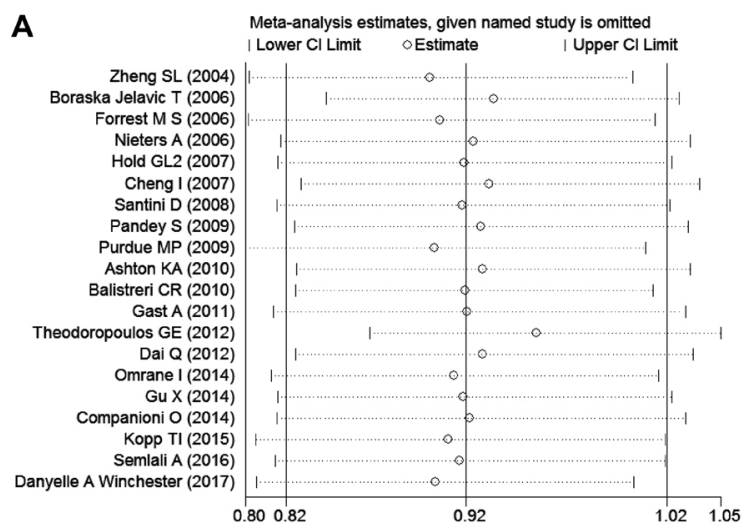

In terms of subgroup analyses classified by race and cancer type, we found that Caucasian female-specific cancer had a conspicuous association with polymorphisms of rs4986790 and rs4986791 and Asian digestive cancer was significantly influenced by rs4986791 polymorphism. There was no evidence for another association between these SNPs and cancer risk.

In summary, this meta-analysis illustrated polymorphisms of TLR4 rs4986791 and rs11536889 might make contributions to slow the formation and development of cancer, whereas rs4986790 was not strongly associated

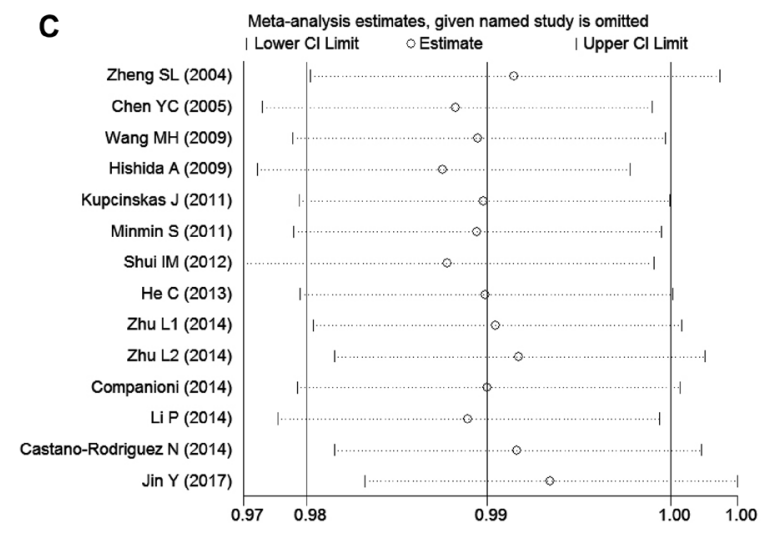

Figure 3: Sensitivity analysis to assess the stability of the meta-analysis about (A) rs4986790, (B) rs4986791 and (C) rs11536889 polymorphisms in overall population under allele model. 
Table 4: Association between TLR4 polymorphisms and overall cancer risk by cancer type

\begin{tabular}{|c|c|c|c|c|c|c|c|c|c|c|c|c|}
\hline \multirow[t]{2}{*}{ Polymorphisms } & \multirow[t]{2}{*}{ Ethnicity } & \multirow{2}{*}{$\begin{array}{c}\text { Cancer } \\
\text { Type }\end{array}$} & \multirow[t]{2}{*}{$N$} & \multicolumn{3}{|l|}{ Allele model } & \multicolumn{2}{|l|}{$\begin{array}{c}\text { Recessive } \\
\text { model }\end{array}$} & \multicolumn{3}{|c|}{$\begin{array}{c}\text { Dominant } \\
\text { model }\end{array}$} & \multirow[b]{2}{*}{$\mathbf{I}^{2}$} \\
\hline & & & & OR $(95 \% \mathrm{CI})$ & POR & $\mathbf{I}^{2}$ & OR $(95 \% C I)$ & POR & $\mathbf{I}^{2}$ & OR(95\%CI) & POR & \\
\hline \multirow[t]{6}{*}{ rs4986790 } & \multirow[t]{6}{*}{ Caucasian } & $\begin{array}{l}\text { Male- } \\
\text { specific }\end{array}$ & 3 & $\begin{array}{c}1.221 \\
(0.921-1.619)\end{array}$ & 0.166 & $25.4 \%$ & $\begin{array}{c}1.162 \\
(0.864-1.563)\end{array}$ & 0.320 & $25.8 \%$ & $\begin{array}{c}5.983 \\
(1.302-27.488)\end{array}$ & 0.021 & $0.0 \%$ \\
\hline & & Digestive & 5 & $\begin{array}{c}0.898 \\
(0.691-1.166)\end{array}$ & 0.420 & $21.7 \%$ & $\begin{array}{c}0.909 \\
(0.729-1.134)\end{array}$ & 0.400 & $3.9 \%$ & $\begin{array}{c}0.791 \\
(0.204-3.064)\end{array}$ & 0.734 & $0.0 \%$ \\
\hline & & Blood & 2 & $\begin{array}{c}0.965 \\
(0.795-1.172)\end{array}$ & 0.722 & $0.0 \%$ & $\begin{array}{c}0.957 \\
(0.782-1.172)\end{array}$ & 0.673 & $0.0 \%$ & $\begin{array}{c}1.207 \\
(0.349-4.178)\end{array}$ & 0.766 & $0.0 \%$ \\
\hline & & $\begin{array}{l}\text { Female- } \\
\text { specific }\end{array}$ & 2 & $\begin{array}{c}0.639 \\
(0.478-0.854)\end{array}$ & 0.002 & $0.0 \%$ & $\begin{array}{c}0.611 \\
(0.447-0.837)\end{array}$ & 0.002 & $0.0 \%$ & $\begin{array}{c}0.679 \\
(0.221-2.090)\end{array}$ & 0.500 & $0.0 \%$ \\
\hline & & Others & 1 & $\begin{array}{c}0.887 \\
(0.650-1.210)\end{array}$ & 0.448 & - & $\begin{array}{c}0.843 \\
(0.610-1.164)\end{array}$ & 0.299 & - & $\begin{array}{c}7.229 \\
(0.373-140.201)\end{array}$ & 0.191 & - \\
\hline & & Overall & 13 & $\begin{array}{c}0.924 \\
(0.796-1.072)\end{array}$ & 0.297 & $43.2 \%$ & $\begin{array}{c}0.906 \\
(0.782-1.049)\end{array}$ & 0.186 & $37.0 \%$ & $\begin{array}{c}1.310 \\
(0.698-2.456)\end{array}$ & 0.400 & $0.0 \%$ \\
\hline \multirow[t]{6}{*}{ rs4986791 } & \multirow[t]{2}{*}{ Asian } & Others & 2 & $\begin{array}{c}0.592 \\
(0.422-0.829)\end{array}$ & 0.002 & $0.0 \%$ & $\begin{array}{c}0.581(0.406- \\
0.833)\end{array}$ & 0.003 & $0.0 \%$ & $\begin{array}{c}0.361 \\
(0.069-1.883)\end{array}$ & 0.227 & $0.0 \%$ \\
\hline & & Digestive & 1 & $\begin{array}{c}0.549 \\
(0.385-0.783)\end{array}$ & 0.001 & - & $\begin{array}{c}0.534 \\
(0.360-0.792)\end{array}$ & 0.002 & - & $\begin{array}{c}0.244 \\
(0.051-1.162)\end{array}$ & 0.076 & - \\
\hline & \multirow[t]{4}{*}{ Caucasian } & Digestive & 13 & $\begin{array}{c}0.720 \\
(0.574-0.902)\end{array}$ & 0.004 & $33.9 \%$ & $\begin{array}{c}0.721 \\
(0.577-0.901)\end{array}$ & 0.004 & $27.5 \%$ & $\begin{array}{c}0.479 \\
(0.159-1.448)\end{array}$ & 0.192 & $3.7 \%$ \\
\hline & & $\begin{array}{l}\text { Female- } \\
\text { specific }\end{array}$ & 3 & $\begin{array}{c}0.851 \\
(0.559-1.296)\end{array}$ & 0.453 & $0.0 \%$ & $\begin{array}{c}0.887 \\
(0.569-1.381)\end{array}$ & 0.594 & $0.0 \%$ & $\begin{array}{c}0.327 \\
(0.047-2.246)\end{array}$ & 0.255 & $0.0 \%$ \\
\hline & & Others & 3 & $\begin{array}{c}1.692 \\
(0.781-3.666)\end{array}$ & 0.182 & $25.7 \%$ & $\begin{array}{c}1.849 \\
(0.923-3.703)\end{array}$ & 0.083 & $5.2 \%$ & $\begin{array}{c}0.159 \\
(0.006-3.967)\end{array}$ & 0.263 & - \\
\hline & & Overall & 19 & $\begin{array}{c}0.790 \\
(0.646-0.966)\end{array}$ & 0.002 & $32.9 \%$ & $\begin{array}{c}0.798 \\
(0.649-0.982)\end{array}$ & 0.033 & $31.3 \%$ & $\begin{array}{c}0.401 \\
(0.162-0.993)\end{array}$ & 0.048 & $0.0 \%$ \\
\hline \multirow[t]{6}{*}{ rs11536889 } & \multirow[t]{3}{*}{ Asian } & Digestive & 7 & $\begin{array}{c}0.937 \\
(0.844-1.041)\end{array}$ & 0.226 & $21.4 \%$ & $\begin{array}{c}0.960 \\
(0.852-1.082)\end{array}$ & 0.503 & $11.6 \%$ & $\begin{array}{c}0.821 \\
(0.658-1.026)\end{array}$ & 0.083 & $0.0 \%$ \\
\hline & & Others & 1 & $\begin{array}{c}0.791 \\
(0.657-0.951)\end{array}$ & 0.013 & - & $\begin{array}{c}0.797 \\
(0.631-1.008)\end{array}$ & 0.059 & - & $\begin{array}{c}0.627 \\
(0.415-0.947)\end{array}$ & 0.026 & - \\
\hline & & Overall & 8 & $\begin{array}{c}0.907 \\
(0.818-1.006)\end{array}$ & 0.066 & $33.7 \%$ & $\begin{array}{c}0.928 \\
(0.826-1.041)\end{array}$ & 0.202 & $20.9 \%$ & $\begin{array}{c}0.773 \\
(0.636-0.940)\end{array}$ & 0.010 & $0.0 \%$ \\
\hline & \multirow[t]{3}{*}{ Caucasian } & $\begin{array}{l}\text { Male- } \\
\text { specific }\end{array}$ & 4 & $\begin{array}{c}0.946 \\
(0.854-1.048)\end{array}$ & 0.287 & $0.0 \%$ & $\begin{array}{c}0.927 \\
(0.809-1.062)\end{array}$ & 0.273 & $25.0 \%$ & $\begin{array}{c}1.071 \\
(0.749-1.533)\end{array}$ & 0.706 & $0.0 \%$ \\
\hline & & Digestive & 2 & $\begin{array}{c}0.924 \\
(0.751-1.136)\end{array}$ & 0.454 & $0.0 \%$ & $\begin{array}{c}0.891 \\
(0.706-1.126)\end{array}$ & 0.334 & $0.0 \%$ & $\begin{array}{c}1.124 \\
(0.571-2.212)\end{array}$ & 0.735 & $0.0 \%$ \\
\hline & & Overall & 6 & $\begin{array}{c}0.941 \\
(0.859-1.032)\end{array}$ & 0.198 & $0.0 \%$ & $\begin{array}{c}0.920 \\
(0.830-1.019)\end{array}$ & 0.110 & $0.0 \%$ & $\begin{array}{c}1.083 \\
(0.789-1.486)\end{array}$ & 0.623 & $0.0 \%$ \\
\hline
\end{tabular}

The results were in bold if the $P_{\mathrm{OR}}<0.05$. Odd ration (OR), 95\% confidence interval $(95 \% \mathrm{CI})$ and POR were tested to evaluate the association, while $\mathrm{I}^{2}$ was examined for heterogeneity.

with cancer risk. Due to the limit of sample size of African population in this study, there is still a requirement of researches including more data for getting insight into association between TLR4 polymorphisms and cancer risk.

\section{MATERIALS AND METHODS}

\section{Identification of eligible studies}

To investigate the association between TLR4 polymorphisms and cancer risk, we searched PubMed and some other databases for relevant articles, ranging from 2000 to 2017 (the last article was published on June 1st, 2017 ). The key words used in searching were
'TLR4 or toll-like receptor' and 'cancer' and 'SNP or polymorphism'. As illustrated in Figure 1, 163 articles from PubMed and 13 articles from other sources were included at first and 55 articles were included eventually.

\section{Data extraction}

Articles meeting all the requirements below were eligible for the analysis:(a) the studies focused on TLR4 and cancer risk;(b) each publication was case-control study and had valuable data for calculating genotype counts;(c) the cancers were classified by the experienced pathologist, according to the World Health Organization (WHO) criteria; (d) the articles were written in English or 
Chinese. The following information is shown in our study: first author, journal, year of publication, ethnicity, cancer type, sample size, genotype and allele frequency.

\section{Statistical analysis}

In this study, we used the software Stata 12.0 (Stata corporation, College Station, TX, USA) for meta-analysis of the association between TLR4 polymorphisms and cancer risk, which was estimated by odds ratio (OR) and $95 \%$ confidence intervals (CI). In addition, we conducted stratification analysis by ethnicity (Caucasian, Asian, African and Mixed populations) and cancer type (digestive cancer was consist of hepatocellular cancer, oral cancer, gastric cancer, esophageal cancer, colon cancer and rectal cancer; male-specific cancer was consist of prostate cancer; female-specific cancer was consist of breast cancer, cervical cancer, endometrial cancer and ovarian cancer; blood cancer was consist of lymphoma and leukemia; one cancer type was ranked into others if the number of studies was less than 3 ) to understand the effects of them on the association. Hardy-Weinberg equilibrium (HWE) was estimated for each study by Pearson Chi-square test in control group and $P<0.05$ was regard a significant departure from HWE. Allele model, recessive model and dominant model were compared to evaluate the association between TLR4 polymorphisms (rs4986790, rs4986791 and rs11536889) and the risk of cancer.

We adopted Begg's test and Funnel plots for evaluation of publication bias of this study and exclusion of one article at a time leading to new pooled ORs, which showed the influence of individual article on the overall consequence. Moreover, to examine heterogeneity among all the articles, the $Q$-test and $I^{2}$ statistics were selected. When the heterogeneity was obvious $\left(\mathrm{P}_{\mathrm{h}}>0.05\right)$, the mixed effects model (the Mantel-Haenszel method) was used for the summary OR value. Otherwise, the random effects model (the DerSimonian and Laird method) took the place of it.

\section{CONFLICTS OF INTEREST}

None.

\section{REFERENCES}

1. Zhao R, Zhang T, Ma B, Li X. Antitumor Activity of Portulaca Oleracea L. Polysaccharide on HeLa Cells Through Inducing TLR4/NF-kappaB Signaling. Nutr Cancer. 2017; 69:131-9. https://doi.org/ 10.1080/01635581.2017.1248294.

2. Wang J, Lin D, Peng H, Shao J, Gu J. Cancer-derived immunoglobulin $\mathrm{G}$ promotes LPS-induced proinflammatory cytokine production via binding to TLR4 in cervical cancer cells. Oncotarget. 2014; 5:9727-43. https://doi.org/ 10.18632/ oncotarget.2359.
3. He A, Shao J, Zhang Y, Lu H, Wu Z, Xu Y. CD200Fc reduces LPS-induced IL-1beta activation in human cervical cancer cells by modulating TLR4-NF-kappaB and NLRP3 inflammasome pathway. Oncotarget. 2017; 8:33214-24. https://doi.org/ 10.18632/oncotarget.16596.

4. Farrugia M, Baron B. The Role of Toll-Like Receptors in Autoimmune Diseases through Failure of the SelfRecognition Mechanism. Int J Inflam. 2017; 2017: 8391230. https://doi.org/ 10.1155/2017/8391230.

5. Che F, Yin J, Quan Y, Xie X, Heng X, Du Y, Wang L. TLR4 interaction with LPS in glioma CD133+ cancer stem cells induces cell proliferation, resistance to chemotherapy and evasion from cytotoxic T lymphocyte-induced cytolysis. Oncotarget. 2017; 8:53495-507. https://doi.org/10.18632/oncotarget.18586.

6. Lu YC, Yeh WC, Ohashi PS. LPS/TLR4 signal transduction pathway. Cytokine. 2008; 42:145-51. https://doi.org/ 10.1016/j.cyto.2008.01.006.

7. Tak PP, Firestein GS. NF-kappaB: a key role in inflammatory diseases. J Clin Invest. 2001; 107:7-11. https://doi.org/ 10.1172/JCI11830.

8. Kang TH, Kim YS, Kim S, Yang B, Lee JJ, Lee HJ, Lee J, Jung ID, Han HD, Lee SH, Koh SS, Wu TC, Park YM. Pancreatic adenocarcinoma upregulated factor serves as adjuvant by activating dendritic cells through stimulation of TLR4. Oncotarget. 2015; 6:27751-62. https://doi.org/ 10.18632/oncotarget.4859.

9. Li G, Wu X, Yang L, He Y, Liu Y, Jin X, Yuan H. TLR4mediated NF-kappaB signaling pathway mediates HMGB1induced pancreatic injury in mice with severe acute pancreatitis. Int J Mol Med. 2016; 37:99-107. https://doi. org/ 10.3892/ijmm.2015.2410.

10. Kim TW, Lee SJ, Oh BM, Lee H, Uhm TG, Min JK, Park YJ, Yoon SR, Kim BY, Kim JW, Choe YK, Lee HG. Epigenetic modification of TLR4 promotes activation of NF-kappaB by regulating methyl-CpG-binding domain protein 2 and $\mathrm{Sp} 1$ in gastric cancer. Oncotarget. 2016; 7:4195-209. https://doi.org/ 10.18632/oncotarget.6549.

11. Yang CX, Li CY, Feng W. Toll-like receptor 4 genetic variants and prognosis of breast cancer. Tissue Antigens. 2013; 81:221-6. https://doi.org/ 10.1111/tan.12096.

12. Theodoropoulos GE, Saridakis V, Karantanos T, Michalopoulos NV, Zagouri F, Kontogianni P, Lymperi M, Gazouli M, Zografos GC. Toll-like receptors gene polymorphisms may confer increased susceptibility to breast cancer development. Breast. 2012; 21:534-8. https:// doi.org/ 10.1016/j.breast.2012.04.001.

13. Semlali A, Jalouli M, Parine NR, Al Amri A, Arafah M, Al Naeem A, Abdullah Ajaj S, Rouabhia M, Alanazi MS. Toll-like receptor 4 as a predictor of clinical outcomes of estrogen receptor-negative breast cancer in Saudi women. Onco Targets Ther. 2017; 10:1207-16. https://doi.org/ 10.2147/OTT.S112165.

14. Etokebe GE, Knezevic J, Petricevic B, Pavelic J, Vrbanec D, Dembic Z. Single-nucleotide polymorphisms in genes encoding toll-like receptor $-2,-3,-4$, and -9 in case-control 
study with breast cancer. Genet Test Mol Biomarkers. 2009; 13:729-34. https://doi.org/ 10.1089/gtmb.2009.0045.

15. Kurt H, Ozbayer C, Bayramoglu A, Gunes HV, Degirmenci I, Oner KS, Metintas M. Determination of the Relationship Between rs4986790 and rs4986791 Variants of TLR4 Gene and Lung Cancer. Inflammation. 2016; 39:166-71. https:// doi.org/ 10.1007/s10753-015-0235-9.

16. Zheng SL, Augustsson-Balter K, Chang B, Hedelin M, Li L, Adami HO, Bensen J, Li G, Johnasson JE, Turner AR, Adams TS, Meyers DA, Isaacs WB, et al. Sequence variants of toll-like receptor 4 are associated with prostate cancer risk: results from the CAncer Prostate in Sweden Study. Cancer Res. 2004; 64:2918-22.

17. Wang MH, Helzlsouer KJ, Smith MW, Hoffman-Bolton JA, Clipp SL, Grinberg V, De Marzo AM, Isaacs WB, Drake CG, Shugart YY, Platz EA. Association of IL10 and other immune response- and obesity-related genes with prostate cancer in CLUE II. Prostate. 2009; 69:874-85. https://doi. org/ 10.1002/pros.20933.

18. Song J, Kim DY, Kim CS, Kim HJ, Lee DH, Lee HM, Ko W, Lee G. The association between Toll-like receptor 4 (TLR4) polymorphisms and the risk of prostate cancer in Korean men. Cancer Genet Cytogenet. 2009; 190:88-92. https://doi.org/ 10.1016/j.cancergencyto.2008.12.011.

19. Shui IM, Stark JR, Penney KL, Schumacher FR, Epstein MM, Pitt MJ, Stampfer MJ, Tamimi RM, Lindstrom S, Sesso HD, Fall K, Ma J, Kraft P, et al. Genetic variation in the toll-like receptor 4 and prostate cancer incidence and mortality. Prostate. 2012; 72:209-16. https://doi.org/ 10.1002/pros.21423.

20. Priyadarshini A, Chakraborti A, Mandal AK, Singh SK. Asp299Gly and Thr399Ile polymorphism of TLR-4 gene in patients with prostate cancer from North India. Indian J Urol. 2013; 29:37-41. https://doi.org/ 10.4103/0970-1591.109982.

21. Cheng I, Plummer SJ, Casey G, Witte JS. Toll-like receptor 4 genetic variation and advanced prostate cancer risk. Cancer Epidemiol Biomarkers Prev. 2007; 16:352-5. https://doi.org/ 10.1158/1055-9965.EPI-06-0429.

22. Zhu L, Wang Y, Jie G, Chi Q, Zhou J, Cui B, Piao D, Zhao Y. Association between Toll-like receptor 4 and interleukin 17 gene polymorphisms and colorectal cancer susceptibility in Northeast China. Med Oncol. 2014; 31: 73. https://doi. org/ 10.1007/s12032-014-0073-x.

23. Semlali A, Reddy Parine N, Arafah M, Mansour L, Azzi A, Al Shahrani O, Al Amri A, Shaik JP, Aljebreen AM, Alharbi O, Almadi MA, Azzam NA, Kohailan M, et al. Expression and Polymorphism of Toll-Like Receptor 4 and Effect on NF-kappaB Mediated Inflammation in Colon Cancer Patients. PLoS One. 2016; 11: e0146333. https://doi.org/ 10.1371/journal.pone.0146333.

24. Proenca MA, de Oliveira JG, Cadamuro AC, Succi M, Netinho JG, Goloni-Bertolo EM, Pavarino EC, Silva AE. TLR2 and TLR4 polymorphisms influence mRNA and protein expression in colorectal cancer. World J Gastroenterol. 2015; 21:7730-41. https://doi.org/ 10.3748/wjg.v21.i25.7730.
25. Pimentel-Nunes $\mathrm{P}$, Teixeira AL, Pereira C, Gomes $\mathrm{M}$, Brandão C, Rodrigues C, Gonçalves N, Boal-Carvalho I, Roncon-Albuquerque R Jr, Moreira-Dias L, LeiteMoreira AF, Medeiros R, Dinis-Ribeiro M. Functional polymorphisms of Toll-like receptors 2 and 4 alter the risk for colorectal carcinoma in Europeans. Dig Liver Dis. 2013; 45:63-9. https://doi.org/ 10.1016/j.dld.2012.08.006.

26. Omrane I, Baroudi O, Kourda N, Bignon YJ, Uhrhammer N, Desrichard A, Medimegh I, Ayari H, Stambouli N, Mezlini A, Bouzayenne H, Marrakchi R, Benammar-Elgaaid A, et al. Positive link between variant Toll-like receptor 4 (Asp299Gly and Thr399Ile) and colorectal cancer patients with advanced stage and lymph node metastasis. Tumor Biol. 2014; 35:54551. https://doi.org/ 10.1007/s13277-013-1075-6.

27. Srivastava K, Srivastava A, Kumar A, Mittal B. Significant association between toll-like receptor gene polymorphisms and gallbladder cancer. Liver Int. 2010; 30:1067-72. https:// doi.org/ 10.1111/j.1478-3231.2010.02268.x.

28. Minmin S, Xiaoqian X, Hao C, Baiyong S, Xiaxing D, Junjie X, Xi Z, Jianquan Z, Songyao J. Single nucleotide polymorphisms of Toll-like receptor 4 decrease the risk of development of hepatocellular carcinoma. PLoS One. 2011; 6: e19466. https://doi.org/ 10.1371/journal.pone.0019466.

29. Agundez JA, Garcia-Martin E, Devesa MJ, Carballo M, Martinez C, Lee-Brunner A, Fernandez C, Diaz-Rubio M, Ladero JM. Polymorphism of the TLR4 gene reduces the risk of hepatitis $\mathrm{C}$ virus-induced hepatocellular carcinoma. Oncology. 2012; 82:35-40. https://doi.org/ 10.1159/000335606.

30. Hold GL, Rabkin CS, Chow WH, Smith MG, Gammon MD, Risch HA, Vaughan TL, McColl KE, Lissowska J, Zatonski W, Schoenberg JB, Blot WJ, Mowat NA, et al. A functional polymorphism of toll-like receptor 4 gene increases risk of gastric carcinoma and its precursors. Gastroenterology. 2007; 132:905-12. https://doi.org/ 10.1053/j.gastro.2006.12.026.

31. Higgins JP, Green S. Cochrane Handbook for Systematic Reviews of Interventions. Naunyn-Schmiedebergs Archiv für experimentelle Pathologie und Pharmakologie. 2008; 5: S38.

32. Zhang X, Wang C, Shan S, Liu X, Jiang Z, Ren T. TLR4/ ROS/miRNA-21 pathway underlies lipopolysaccharide instructed primary tumor outgrowth in lung cancer patients. Oncotarget. 2016; 7:42172-82. https://doi.org/ 10.18632/ oncotarget.9902.

33. Zhu G, Huang Q, Huang Y, Zheng W, Hua J, Yang S, Zhuang J, Wang J, Ye J. Lipopolysaccharide increases the release of VEGF-C that enhances cell motility and promotes lymphangiogenesis and lymphatic metastasis through the TLR4- NF-kappaB/JNK pathways in colorectal cancer. Oncotarget. 2016; 7:73711-24. https://doi.org/ 10.18632/ oncotarget.12449.

34. Hold GL, Berry S, Saunders KA, Drew J, Mayer C, Brookes H, Gay NJ, El-Omar EM, Bryant CE. The TLR4 D299G and T399I SNPs are constitutively active to up-regulate expression of Trif-dependent genes. PLoS One. 2014; 9: e111460. https://doi.org/ 10.1371/journal.pone.0111460. 
35. Arbour NC, Lorenz E, Schutte BC, Zabner J, Kline JN, Jones M, Frees K, Watt JL, Schwartz DA. TLR4 mutations are associated with endotoxin hyporesponsiveness in humans. Nat Genet. 2000; 25:187-91. https://doi.org/ 10.1038/76048.

36. Lorenz E, Mira JP, Frees KL, Schwartz DA. Relevance of mutations in the TLR4 receptor in patients with gramnegative septic shock. Arch Intern Med. 2002; 162:1028-32.

37. Kiechl S, Lorenz E, Reindl M, Wiedermann CJ, Oberhollenzer F, Bonora E, Willeit J, Schwartz DA. Tolllike receptor 4 polymorphisms and atherogenesis. N Engl J Med. 2002; 347:185-92.

38. Qadri Q, Rasool R, Afroze D, Naqash S, Gulzar GM, Yousuf A, Siddiqi MA, Shah ZA. Study of TLR4 and IL-8 gene polymorphisms in H.pylori-induced inflammation in gastric cancer in an ethnic Kashmiri population. Immunol Invest. 2014; 43:324-36. https://doi.org/ 10.3109/08820139.2013.854378.

39. de Oliveira JG, Rossi AF, Nizato DM, Miyasaki K, Silva AE. Profiles of gene polymorphisms in cytokines and Toll-like receptors with higher risk for gastric cancer. Dig Dis Sci. 2013; 58:978-88. https://doi.org/ 10.1007/s10620-012-2460-5.

40. Shen Y, Liu Y, Liu S, Zhang A. Toll-like receptor 4 gene polymorphisms and susceptibility to bladder cancer. Pathol Oncol Res. 2013; 19:275-80. https://doi.org/ 10.1007/ s12253-012-9579-8.

41. Rybka J, Gebura K, Wrobel T, Wysoczanska B, Stefanko E, Kuliczkowski K, Bogunia-Kubik K. Variations in genes involved in regulation of the nuclear factor - kappaB pathway and the risk of acute myeloid leukaemia. Int J Immunogenet. 2016; 43:101-6. https://doi.org/ 10.1111/iji.12255.

42. Sato K, Yoshimura A, Kaneko T, Ukai T, Ozaki Y, Nakamura H, Li X, Matsumura H, Hara Y, Ogata Y. A single nucleotide polymorphism in 3'-untranslated region contributes to the regulation of Toll-like receptor 4 translation. J Biol Chem. 2012; 287:25163-72.

43. Castano-Rodriguez N, Kaakoush NO, Pardo AL, Goh KL, Fock KM, Mitchell HM. Genetic polymorphisms in the Toll-like receptor signalling pathway in Helicobacter pylori infection and related gastric cancer. Hum Immunol. 2014; 75:808-15. https://doi.org/ 10.1016/j. humimm.2014.06.001.

44. Jin Y, Qiu S, Shao N, Zheng J. Association of toll-like receptor gene polymorphisms and its interaction with HPV infection in determining the susceptibility of cervical cancer in Chinese Han population. Mamm Genome. 2017; 28:2139. https://doi.org/ 10.1007/s00335-017-9691-x.

45. Chen YC, Giovannucci E, Lazarus R, Kraft P, Ketkar S, Hunter DJ. Sequence variants of Toll-like receptor 4 and susceptibility to prostate cancer. Cancer Res. 2005; 65:1177178. https://doi.org/10.1158/0008-5472.CAN-05-2078.

46. Boraska Jelavić T, Barisić M, Drmic Hofman I, Boraska V, Vrdoljak E, Peruzović M, Hozo I, Puljiz Z, Terzić J. Microsatelite GT polymorphism in the toll-like receptor 2 is associated with colorectal cancer. Clin Genet. 2006; 70:15660. https://doi.org/10.1111/j.1399-0004.2006.00651.x.
47. Forrest MS, Skibola CF, Lightfoot TJ, Bracci PM, Willett EV, Smith MT, Holly EA, Roman E. Polymorphisms in innate immunity genes and risk of non-Hodgkin lymphoma. Br J Haematol. 2006; 134:180-83. https://doi.org/10.1111/j.13652141.2006.06141.x.

48. Nieters A, Beckmann L, Deeg E, Becker N. Gene polymorphisms in Toll-like receptors, interleukin-10, and interleukin-10 receptor alpha and lymphoma risk. Genes Immun. 2006; 7:615-24. https://doi.org/10.1038/ sj.gene. 6364337.

49. Santini D, Angeletti S, Ruzzo A, Dicuonzo G, Galluzzo S, Vincenzi B, Calvieri A, Pizzagalli F, Graziano N, Ferraro E, Lorino G, Altomare A, Magnani M, et al. Toll-like receptor 4 Asp299Gly and Thr399Ile polymorphisms in gastric cancer of intestinal and diffuse histotypes. Clin Exp Immunol. 2008; 154:360-64. https://doi.org/10.1111/j.13652249.2008.03776.x

50. Pandey S, Mittal RD, Srivastava M, Srivastava K, Singh S, Srivastava S, Mittal B. Impact of Toll-like receptors [TLR] 2 (-196 to $-174 \mathrm{del})$ and TLR 4 (Asp299Gly, Thr399Ile) in cervical cancer susceptibility in North Indian women. Gynecol Oncol. 2009; 114:501-05. https://doi.org/10.1016/j. ygyno.2009.05.032.

51. Purdue MP, Lan Q, Wang SS, Kricker A, Menashe I, Zheng TZ, Hartge P, Grulich AE, Zhang Y, Morton LM, Vajdic CM, Holford TR, Severson RK, et al. A pooled investigation of Toll-like receptor gene variants and risk of non-Hodgkin lymphoma. Carcinogenesis. 2009; 30:275-81. https://doi. org/10.1093/carcin/bgn262.

52. Ashton KA, Proietto A, Otton G, Symonds I, McEvoy M, Attia J, Scott RJ. Toll-like receptor (TLR) and nucleosomebinding oligomerization domain (NOD) gene polymorphisms and endometrial cancer risk. BMC Cancer. 2010; 10:382. https://doi.org/10.1186/1471-2407-10-382.

53. Balistreri CR, Caruso C, Carruba G, Miceli V, Campisi I, Listì F, Lio D, Colonna-Romano G, Candore G. A pilot study on prostate cancer risk and pro-inflammatory genotypes: pathophysiology and therapeutic implications. Curr Pharm Des. 2010; 16:718-24. https://doi.org/10.2174/1381612107 90883877.

54. Gast A, Bermejo JL, Claus R, Brandt A, Weires M, Weber A, Plass C, Sucker A, Hemminki K, Schadendorf D, Kumar R. Association of inherited variation in Toll-like receptor genes with malignant melanoma susceptibility and survival. PLoS One. 2011; 6:e24370. https://doi.org/10.1371/journal. pone.0024370.

55. Yang ZH, Dai Q, Gu YJ, Guo QX, Gong L. Cytokine and chemokine modification by Toll-like receptor polymorphisms is associated with nasopharyngeal carcinoma. Cancer Sci. 2012; 103:653-58. https://doi.org/10.1111/j.13497006.2012.02210.x.

56. Dai Q, Zhong L, Zhang X, Yang Z. Expression of IL$1 \alpha$ and TNF- $\alpha$ modified by Toll-like receptor 4 genetic polymorphism is associated with colorectal carcinoma. Chin J Pathophysiol. 2012; 28:1976-78. https://doi.org/10.3969/j. issn.1000-4718.2012.11.011. 
57. Gu X, Shen Y, Fu L, Zuo HY, Yasen H, He P, Guo XH, Shi YW, Yusufu M. Polymorphic variation of inflammationrelated genes and risk of non-Hodgkin lymphoma for Uygur and Han Chinese in Xinjiang. Asian Pac J Cancer Prev. 2014; 15:9177-83. https://doi.org/10.7314/APJCP.2014.15.21.9177.

58. Companioni O, Bonet C, Muñoz X, Weiderpass E, Panico S, Tumino R, Palli D, Agnoli C, Vineis P, Boutron-Ruault MC, Racine A, Clavel-Chapelon F, Travis RC, et al. Polymorphisms of Helicobacter pylori signaling pathway genes and gastric cancer risk in the European Prospective Investigation into Cancer-Eurgast cohort. Int J Cancer. 2014; 134:92-101. https://doi.org/10.1002/ijc.28357.

59. Kopp TI, Andersen V, Tjonneland A, Vogel U. Polymorphisms in NFKB1 and TLR4 and interaction with dietary and life style factors in relation to colorectal cancer in a Danish prospective case-cohort study. PLoS One. 2015; 10:e0116394. https://doi.org/10.1371/journal.pone.0116394.

60. Winchester DA, Till C, Goodman PJ, Tangen CM, Santella RM, Johnson-Pais TL, Leach RJ, Xu J, Zheng SL, Thompson IM, Lucia MS, Lippmann SM, Parnes HL, et al. Variation in genes involved in the immune response and prostate cancer risk in the placebo arm of the Prostate Cancer Prevention Trial. Prostate. 2015; 75:1403-18. https://doi.org/10.1002/ pros.23021.

61. Zidi S, Sghaier I, Gazouani E, Mezlini A, YacoubiLoueslati B. Evaluation of Toll-Like Receptors 2/3/4/9 Gene Polymorphisms in Cervical Cancer Evolution. Pathol Oncol Res. 2016; 22:323-30. https://doi.org/10.1007/s12253-0150009-6.

62. Winchester DA, Till C, Goodman PJ, Tangen CM, Santella RM, Johnson-Pais TL, Leach RJ, Xu J, Zheng SL, Thompson IM, Lucia MS, Lippman SM, Parnes HL, et al. Association between variants in genes involved in the immune response and prostate cancer risk in men randomized to the finasteride arm in the Prostate Cancer Prevention Trial. Prostate. 2017; 77:908-19. https://doi.org/10.1002/pros.23346.

63. Garza-Gonzalez E, Bosques-Padilla FJ, Mendoza-Ibarra SI, Flores-Gutierrez JP, Maldonado-Garza HJ, Perez-Perez GI. Assessment of the toll-like receptor 4 Asp299Gly, Thr399Ile and interleukin-8 -251 polymorphisms in the risk for the development of distal gastric cancer. BMC Cancer. 2007; 7:70. https://doi.org/10.1186/1471-2407-7-70.

64. Trejo-de la O A, Torres J, Pérez-Rodríguez M, CamorlingaPonce M, Luna LF, Abdo-Francis JM, Lazcano E, Maldonado-Bernal C, and Trejo-de la OA. TLR4 singlenucleotide polymorphisms alter mucosal cytokine and chemokine patterns in Mexican patients with Helicobacter pylori-associated gastroduodenal diseases. Clin Immunol. 2008; 129:333-40. https://doi.org/10.1016/j.clim.2008.07.00.

65. Rigoli L, Di Bella C, Fedele F, Procopio V, Amorini M, Lo Giudice G, Romeo P, Pugliatti F, Finocchiaro
G, Lucianò R, Caruso RA. TLR4 and NOD2/CARD15 genetic polymorphisms and their possible role in gastric carcinogenesis. Anticancer Res. 2010; 30:513-17.

66. Davoodi H, Seow HF. Variant Toll-like receptor4 (Asp299Gly and Thr399Ile alleles) and Toll-like receptor2 (Arg753Gln and Arg677Trp alleles) in colorectal cancer. Iran J Allergy Asthma Immunol. 2011; 10:91-9.

67. Singh V, Srivastava N, Kapoor R, Mittal RD. Singlenucleotide polymorphisms in genes encoding toll-like receptor $-2,-3,-4$, and -9 in a case-control study with bladder cancer susceptibility in a North Indian population. Arch Med Res. 2013; 44:54-61. https://doi.org/10.1016/j. arcmed.2012.10.008.

68. de Oliveira JG, Silva AE. Polymorphisms of the TLR2 and TLR4 genes are associated with risk of gastric cancer in a Brazilian population. World J Gastroenterol. 2012; 18:123542. https://doi.org/10.3748/wjg.v18.i11.1235.

69. Kutikhin AG, Yuzhalin AE, Volkov AN, Zhivotovskiy AS, Brusina EB. Correlation between genetic polymorphisms within IL-1B and TLR4 genes and cancer risk in a Russian population: a case-control study. Tumour Biol. 2014; 35:4821-30. https://doi.org/10.1007/s13277-014-1633-6.

70. Zeljic K, Supic G, Jovic N, Kozomara R, Brankovic-Magic M, Obrenovic M, Magic Z. Association of TLR2, TLR3, TLR4 and CD14 genes polymorphisms with oral cancer risk and survival. Oral Dis. 2014; 20:416-24. https://doi. org/10.1111/odi.12144.

71. Hishida A, Matsuo K, Goto Y, Mitsuda Y, Hiraki A, Naito M, Wakai K, Tajima K, Hamajima N. Toll-like receptor $4+3725$ G/C polymorphism, Helicobacter pylori seropositivity, and the risk of gastric atrophy and gastric cancer in Japanese. Helicobacter. 2009; 14:47-53. https://doi.org/10.1111/j.15235378.2009.00659.x.

72. Kupcinskas J, Wex T, Bornschein J, Selgrad M, Leja M, Juozaityte E, Kiudelis G, Jonaitis L, Malfertheiner P. Lack of association between gene polymorphisms of Angiotensin converting enzyme, Nod-like receptor 1, Toll-like receptor 4, FAS/FASL and the presence of Helicobacter pyloriinduced premalignant gastric lesions and gastric cancer in Caucasians. BMC Med Genet. 2011; 12:112. https://doi. org/10.1186/1471-2350-12-112.

73. He C, Tu H, Sun L, Xu Q, Li P, Gong Y, Dong N, Yuan Y. Helicobacter pylori-related host gene polymorphisms associated with susceptibility of gastric carcinogenesis: a twostage case-control study in Chinese. Carcinogenesis. 2013; 34:1450-57. https://doi.org/10.1093/carcin/bgt079.

74. Li P, He CY, Xu Q, Sun LP, Ha MW, Yuan Y. Effect of the -2081G/A polymorphism of the TLR4 gene and its interaction with Helicobacter pylori infection on the risk of gastric cancer in Chinese individuals. Genet Test Mol Biomarkers. 2014; 18:610-15. https://doi.org/10.1089/gtmb.2014.0047. 